\title{
PENGARUH KEINGINTAHUAN DAN RASA PERCAYA DIRI SISWA TERHADAP HASIL BELAJAR MATEMATIKA KELAS VII MTS NEGERI I KOTA CIREBON
}

\section{THE INFLUENCE OF CURIOSITY AND SELF-CONFIDENCE OF STUDENTS TOWARD OUTCOME STUDIED MATHEMATICS GRADE VII MTS NEGERI 1 CIREBON}

\author{
Irna Hanifah Ameliah, Mumun Munawaroh, Arif Muchyidin \\ Tadris Matematika, IAIN Syekh Nurjati Cirebon \\ Jalan perjuangan Bypass Sunyaragi
}

\begin{abstract}
In the world of education right now, a lot of complex issues occur and need special attention from all parties. One of them is the lack of curiosity and self-confidence of students thus affecting student learning results primarily on mathematical subjects. The better the curiosity and self-confidence of students, then students will be more motivated to learn. So the students will obtain a meaningful learning and get the results of the study are in accordance with the national education goals. The purpose of this research was to review; How big is the curiosity of students, how high the confidence of students, and how great the influence of curiosity and self-confidence of students toward outcome studied mathematics students. The research method used is the quantitative methods. The population in this research is grade VII MTs Negeri 1 Cirebon in the year 2014/2015 Lessons, with the number of students 1127 people. The technique of sampling using purporsive sampling. By using the selected sampling engineering 80 students to become respondents. The dwarf in the collection of data for the variable $X$ is now with the spread against the target of research. As for the variable $Y$ by using the test instrument. Then the data obtained were analyzed by using test normality, test its homogeneity, linierity test regression, autocorrelation test, and test the multikolinieritas as well as a test of the hypothesis. Based on the results of the analysis of the obtained an average score of curiosity is 59,25\% by category and average score results of learning math is $69,11 \%$ with high category as well a the average score of studen learning outcomes i.e. 67,81\% by category enough. The result statistical hypothesis test note that 11,782>2,37 the Ho are received. With equation regresion is $83.866+0.1280 .364 \times 1+X 2$ which means there are influences between curiosity and self-confidence of students toward outcome studied mathematics. Based on the determination of the magnitude of the influence coefficient is 4,79\% meaning that curiosity and self-confidence of students gives only a small influence against the results of the study of mathematics students. While the rest of 95,21\% is affected by other factors.
\end{abstract}

Key words: students 'Curiosity, self-confidence of the students, the results of the study

\section{PENDAHULUAN}

Pendidikan merupakan salah satu bagian dari kebutuhan pokok bagi setiap insan yang hidup di dunia ini. Tanpa pendidikan, manusia tidak akan mengalami perubahan hidup, moral manusia akan hancur, kesejahteraan hidup pun akan sulit untuk dicapai. Karena itu, pendidikan sangat penting bagi kelangsungan hidup manusia untuk bertahan hidup, juga menentukan arah dan tujuan hidupnya. Menurut Saodih Pendidikan merupakan interaksi antara pendidik dengan siswa, untuk mencapai tujuan pendidikan yang berlangsung dalam lingkungan tertentu. Proses belajar tidak terlepas dari adanya interaksi antara guru dengan siswa untuk memperoleh suatu tujuan yang ingin dicapainya. Guru memiliki peran yang sangat penting 
dalam menentukan kuantitas dan kualitas pengajaran yang dilaksakannya (Ilawati, dkk. 2015).

Menurut Muhibbin (1999:98) proses belajar didefinisikan sebagai perubahan perilaku afektif, kognitif, psikomotor, yang bersifat positif dalam arti berorientasi kearah yang lebih maju dari pada keadaan sebelumnya. Tetapi, dalam proses pembelajaran tidak jarang guru menemukan kendala. Sehingga tujuan dari pendidikan nasional belum maksimal dicapai. Terutama pada mata pelajaran matematika. Seringkali siswa men'judge' mata pelajaran matematika itu sulit. Imbasnya siswa tidak memiliki keinginan untuk mencoba memahami materi matematika yang diajarkan. Belum lagi ketidakyakinan siswa akan kemampuan yang dimilikinya yang menambah siswa sulit mengembangkan potensinya pada mata pelajaran matematika.

Keingintahuan dan rasa percaya diri seorang siswa merupakan faktor internal yang mempengaruhi proses pembelajaran di kelas. Siswa diharapkan dapat menyukai tantangan, berinovasi dan kreatif dalam menciptakan sesuatu yang dapat membanggakan dirinya, keluarga dan negara. Rasa ingin tahu merupakan modal awal bagi siswa dalam proses pembelajaran. Adanya rasa ingin tahu, akan mendorong siswa untuk memenuhi rasa ingin tahunya. Demi memenuhi rasa ingin tahunya itulah yang akan membawa siswa pada proses mencari lalu menemukan. Usaha-usaha yang dapat dilakukan siswa dalam proses mencari diantaranya yaitu bertanya langsung kepada guru, berdiskusi dengan teman dan mencari beberapa bahan materi di beberapa sumber buku lain selain buku pegangan ataupun internet.

Rasa ingin tahu akan mantap jika siswa tersebut memiliki rasa percaya diri yang tinggi. Tidak jarang siswa memiliki pertanyaan tetapi mereka takut untuk bertanya, tidak jarang juga siswa memiliki argumen namun tidak disampaikan karena malu dan takut salah, tidak sedikit pula siswa yang tidak yakin atas apa yang sudah mereka usahakan. Rasa percaya diri merupakan suatu perasaan keyakinan dan sikap seseorang terhadap kemampuan yang dimilikinya dengan ikhlas menerima apa adanya baik secara positif maupun negatif yang dibentuk dan dipelajari melalui proses belajar dengan tujuan untuk kebahagiaan dirinya. Keyakinan dan penilaian positif akan membuat seseorang termotivasi untuk belajar sehingga memperoleh prestai yang memuaskan. Menurut Pudjijugjanti dalam bukunya Konsep Diri dalam Pendidikan (1988: 1-2) mengatakan bahwa dari berbagai pengamatan yang dilakukan ternyata banyak siswa yang mengalami kegagalandalam pelajaran bukan disebabkan oleh tingkat intelegensi yang rendah atau keadaan fisik yang lemah, melainkan oleh adanya perasaan tidak mampu untuk

melakukan tugas.

Percaya diri merupakan salah satu karakter yang penting ditanamkan. Siswa menjadi generasi yang tidak mudah dipengaruhi oleh hal-hal negatif yang berasal dari lingkungan sekitar, percaya diri membuat siswa menjadi optimis dan tegar dalam menghadapi berbagai masalah yang dihadapinya dalam proses pembelajaran dan mampu menyelesaikan permasalahan tersebut dengan mengoptimalkan segala kemampuan yang dimiliki oleh siswa.

Karakter keingintahuan dan rasa percaya diri siswa tidak serta merta muncul begitu saja. Tetapi, harus dibina sejak dini. Penanaman nilai karakter yang terintgrasi dalam semua mata pelajaran khususnya matematika, dapat diharapkan nilai-nilai tersebut tertanam dalam diri siswa. Materi yang diajarkan tidak hanya sebagai pengetahuan sekolah, tetapi juga menjadi pengetahuan dalam diri siswa yang akhirnya ditunjukkan dalam bentuk perilaku.

\section{LANDASAN TEORI}

Sulistyowati (2012:74) berpendapat ingin tahu adalah sikap dan tindakan yang selalu 
berupaya untuk mengetahui lebih mendalam dan meluas dari apa yang dipelajarinya, dilihat dan didengar. Istilah itu juga dapat digunakan untuk menunjukkan perilaku itu sendiri yang disebabkan oleh emosi ingin tahu, karena emosi ini mewakili kehendak untuk mengetahui hal-hal baru, rasa ingin tahu diibaratkan "bensin" atau kendaraan ilmu dan disiplin lain dalam studi yang dilakukan oleh manusia.

Abdullah (2011: 2) menjelaskan bahwa manusia dapat menemukan berbagai cara untuk melindungi diri dari pengaruh lingkungan yang merugikan karena adanya akal budi. Adanya akal budi menimbulkan rasa ingin tahu yang selalu berkembang. Rasa ingin tahu tidak akan pernah terpuaskan. Selanjutnya, Jasin (2002: 3) menjelaskan apabila manusia telah berhasil memecahkan suatu persoalan, maka akan timbul masalah lain yang ingin dipecahkannya. Manusia akan bertanya terus setelah tahu "apanya", maka ingin tahu "bagaimana" dan "mengapa".

Menurut Chaplin (Bundu, 2006:137) sikap dinyatakan sebagai suatukecenderungan yang relatif stabil dan berlangsung terus menerus untuk bertingkah laku atau untuk mereaksi dengan cara tertentu. Lebih lanjut lagi, Cassio dan Gibson (Bundu, 2006:138) menjelaskan bahwa sikap berkembang dari interaksi antara individu dengan lingkungan melalui kognisi dari interaksi dan konsistensi sikap dibentuk menjadi komponen kognisi, emosi dan kecenderungan bertindak. Setelah sikap terbentuk akan mempengaruhi perilaku secara langsung. Bundu (2006: 13) menjelaskan bahwa sikap ilmiah adalah suatu sikap yang dimiliki para ilmuan dalam mencari dan mengembangkan pengetahuan baru. Burhanudin Salam (2005: 38) menjelaskan bahwa sikap ilmiah merupakan suatu pandangan seseorang terhadap cara berpikir yang sesuai dengan metode keilmuan, sehingga akan timbul kecenderungan untuk menerima ataupun menolak terhadap cara berpikir yang sesuai dengan keilmuan tersebut. Seorang ilmuan jelas harus memiliki sikap yang positif, atau kecenderungan untuk menerima cara berpikir yang sesuai dengan metode keilmuan, yang dimanifestasikan di dalam kognisinya, emosi atau perasaan, serta di dalam perilakunya.

Pada kegiatan belajar sikap, upaya pendidik ialah membantu siswa untuk memiliki dan mengembangkan perubahan sikap. Berkaitan dengan hal tersebut, maka kegiatan belajar perlu dirancang dengan baik dan memuat tujuan belajar, bahan belajar, dan teknik pembelajaran yang cocok untuk memiliki dan mengembangkan sikap. Sudjana (2000: 137) mengemukakan patokan-patokan yang dapat digunakan pendidik dalam membantu siswa melakukan kegiatan belajar sikap adalah sebagai berikut: a) menyusun dan menyajikan bahan belajar sebagai stimulus; b) menumbuhkan suasana belajar partisipatif; c) menjadi contoh bagi siswa dalam melakukan tindakan yang sesuai dengan sikap baru yang telah ditentukan; d) kegiatan belajar yang mendukung timbulnya sikap baru dilakukan melalui keiatan belajar kelompok e) latihan untuk mengembangkan kegiatan siswa dalam sikap baru yang dimiikinya perlu diberikan.

Tabel 1 Ciri-ciri Sikap Ilmiah Siswa

\begin{tabular}{|l|l|}
\hline Sikap Ilmiah & Ciri-ciri yang dapat diamati \\
\hline $\begin{array}{l}\text { Sikap ingin tahu } \\
\text { (curiosity) }\end{array}$ & $\begin{array}{l}\text { Menggunakan beberapa alat indera untuk menyelidiki materi materi } \\
\text { Mengajukan pertanyaan tentang objek dan peristiwa. } \\
\text { Memperlihatkan minat pada hasil percobaan }\end{array}$ \\
\hline $\begin{array}{l}\text { Sikap penemuan } \\
\text { (inventiveness) }\end{array}$ & $\begin{array}{l}\text { Menggunakan alat tidak seperti biasanya dan dengan cara-cara yang } \\
\text { konstruktif, menyarankan percobaan-percobaan baru } \\
\text { Menguraikan konklusi baru dari pengamatan mereka }\end{array}$ \\
\hline
\end{tabular}




\begin{tabular}{|l|l|}
\hline $\begin{array}{l}\text { Berpikir kritis } \\
\text { (critical } \\
\text { thingking) }\end{array}$ & $\begin{array}{l}\text { Menggunakan fakta-fakta untuk dasar konklusi mereka } \\
\text { Menunjukan laporan yang berbeda dengan teman kelasnya } \\
\text { Merubah pendapat dalam merespon terhadap fakta }\end{array}$ \\
\hline $\begin{array}{l}\text { Ketekunan } \\
\text { (persistence) }\end{array}$ & $\begin{array}{l}\text { elanjutkan meneliti sesuatu sesudah "kebaruannya" hilang } \\
\text { Mengulangi satu percobaan meskipun berakibat kegagalan } \\
\text { Melengkapi satu kegiatan meskipun teman kelasnya selesai lebih } \\
\text { awal }\end{array}$ \\
\hline
\end{tabular}

Mustari ( 2011: 109) berpendapat bahwa untuk mengembangkan rasa ingin tahu pada anak, kebebasan anak itu sendiri harus ada untuk melakukan dan melayani rasa ingin tahunya. Seseorang tidak bisa begitu saja menghardik seseorang tidak tahu atau malas saat bertanya. Lebih baik adalah memberikan kesempatan kepada orang lain bagaimana cara-cara untuk mencari jawaban. Misalnya, apabila pertanyaan tentang pemecahan masalah dalam persoalan matematika, maka berilah contoh kepada anak tersebut bagaimana rumus dan cara-cara penyelesaian yang tepat.

Percaya diri merupakan keyakinan dalam diri seseorang untuk dapat menangani segala sesuatu yang ada dihadapannya dengan tenang. Percaya diri merupakan keyakinan yang kuat dalam diri yang berupa perasaan dan anggapan bahwa dirinya dalam keadaan baik sehingga memungkinkan individu tampil dan berperilaku dengan penuh keyakinan (Hambly, 1995:3).

Menurut Hakim (2002 : 6) rasa percaya diri secara sederhana dapat diartikan sebagai suatu keyakinan seseorang terhadap segala aspek kelebihan yang dimilikinya dan keyakinan tersebut membuatnya merasa mampu untuk bisa mencapai berbagai tujuan di dalam hidupnya. Salah satu karakter yang penting ditanamkan kepada siswa adalah karakter percaya diri. Percaya diri diartikan sebagai sikap yakin akan kemampuan diri sendiri terhadap pemenuhan tercapainya setiap keinginan dan harapannya (Salirawati, 2012)

Menurut Hakim (2005:5-6) ciri-ciri orang yang percaya diri antara lain: a) selalu bersikap tenang di dalam mengerjakan segala sesuatu; b) mempunyai potensi dan kemampuan yang memadai; c) mampu menetralisasi ketegangan di dalam berbagai situasi; d) mampu menyesuaikan diri dan berkomunikasi di berbagai situasi; f) memiliki kondisi mental dan fisik yang cukup; g) memiliki kecerdasan yang cukup dan tingkat pendidikan formal yang cukup; h) memiliki keahlian atau keterampilan lain yang menunjang kehidupannya, misalnya keterampilan berbahasa asing; i) memiliki kemampuan bersosialisasi; j) memiliki latar belakang pendidikan keluarga yang baik; $\mathrm{k}$ ) memiliki pengalaman hidup yang menempa mentalnya menjadi kuat dan tahan di dalam menghadapi berbagai cobaan hidup; 1) selalu bereaksi positif di dalam menghadapi berbagai masalah, misalnya dengan tetap tegar, sabar, dan tabah dalam menghadapi persoalan hidup.

Hasil belajar matematika merupakan kapasitas dan kapabilitas yang dimiliki oleh siswa setelah menerima pengalaman dalam belajar matematika (Sudjana, 1997:10). Sedangkan Gagne (dalam Willis, 2002 : 134) mengungkapkan hasil belajar sebagai kapasitas atau kemampuan yang diperoleh dari proses belajar meliputi lima katagori hasil belajar, yaitu: a) Ketrampilan intelektual, b) Informasi verbal, c) Strategi kognitif, d) Ketrampilan kognitif, dan e) Sikap atau nilai-nilai.

\section{METODOLOGI PENELITIAN}

Penelitian ini dilaksanakan di MTs Negeri 1 Kota Cirebon Tahun Ajaran 2014/2015. Alamat J1. Pilang No.38 Kelurahan Sukapura Kec. Kejaksan Kota Cirebon. Metode penelitian yang penulis tempuh dalam penelitian ini yaitu dengan menggunakan metode penelitian kuantitatif, adalah penelitian yang dilakukan untuk mengetahui salah satu aspek dari sasaran penelitian secara meluas 
walaupun dalam pengumpulan datanya menggunakan teknik pengambilan sampel. Populasi dalam penelitian ini adalah seluruh siswa MTs Negeri 1 Kota Cirebon yang terdiri dari 27 kelas dan berjumlah 1.127 siswa dengan populasi targetnya adalah seluruh kelas VII yang terdiri dari 9 kelas dengan jumlah siswa sebanyak 387 siswa. Instrumen angket merupakan teknik pengumpulan data keingin tahuan siswa dan rasa percaya diri sswa. Sedangkan tes adalah teknik pengumpulan data untuk hasil belajar.

Skala pengukuran yang digunakan peneliti adalah skala likert yang berbentuk data ordinal. Data keingintahuan (variabel X) dan rasa percaya diri siswa sengan alternatif jawaban selalu (SL), sering (SR), kadangkadang (KD), jarang (J) dan tidak pernah (TP). Data keingintahuan dan rasa percaya diri siswa merupakan data ordinal. Data ordinal merupakan kualitatif yang memiliki ciri membedakan, mengurutkan,, memperingkatkan dan berjenjang (bukan

Berdasarkan hasil perhitungan dengan menggunakan program SPSS. 17.0, diperoleh output analisis statistik. Hasil tersebut menunjukkan bahwa skor minimal yang diperoleh siswa terkait keingintahuan siswa adalah 43, sedangkan skor maksimal yang diperoleh siswa adalah 86 . Skor ratarata (mean) keingintahuan siswa siswa diperoleh 63,34. Adapun standar deviasi berupa angka tapi berupa kata atau kalimat seperti selalu, sering, kadang-kadang, jarang, dan tidak pernah. Data ordinal dapat diolah dalam analisis data ketika data itu berbentuk data interval.

\section{HASIL DAN PEMBAHASAN}

Keingintahuan siswa merupakan perasaan yang timbul dalam diri seseorang untuk mengetahui apa yang ingin diketahuinya. Peneliti menyebarkan angket berisi 25 pernyataan dengan 5 alternatif jawaban untuk mengetahui tingkat keingintahuan siswa. Adapun dalam pengolahannya peneliti mengubah data mentah ke dalam data baku yang menggunakan skor berskala dari 1 sampai 5, artinya skor maksimal yang diperoleh responden untuk masing-masing itemnya adalah 5 dan skor minimalnya adalah 1. Dari hasil penyebaran angket tersebut, dengan menggunakan program SPSS 17.0 diperoleh data deskripsi statistik yang dapat dilihat pata tabel 2 sebagai berikut :

yang diperoleh melalui skala keingintahuan siswa adalah10,644 dan nilai variannya sebesar 113,297. Hal ini menunjukkan bahwa data tersebut bervariasi.

Berdasarkan analisis data angket yang dilakukan, maka secara keseluruhan hasil deskriptif variabel keingintahun siswa dapat dilihat sebagai berikut

Descriptive Statisties

\begin{tabular}{|l|l|l|l|l|l|l|}
\hline & Minimum & Maximum & Mcan & $\begin{array}{l}\text { Std. } \\
\text { Deviation }\end{array}$ & Variance \\
\hline $\begin{array}{l}\text { Keingintahuon } \\
\text { SIswa } \\
\text { Valid N (listwisc) }\end{array}$ & 80 & 43 & 80 & 63.34 & 10.044 & 113.297 \\
\hline
\end{tabular}


Rekapitulasi Keingintahuan Siswa

\begin{tabular}{|c|c|c|c|}
\hline No & Indikatur & Interpretasi( $\%)$ & Ket. \\
\hline 1. & Menanyakan gagasan sendiri atau orang lain & 66,46 & Tinggi \\
\hline 2. & Berinisictif menambah wawasan & 61.7 & Cukup \\
\hline 3. & Respon positif siswa dalam pembelajeran & 75,77 & Tinggi \\
\hline 4. & Bcrkontribusi dalam diskusi & 58,09 & Cukup \\
\hline 5. & Siswa menjadi pengamat yang baik & 59,26 & Cukup \\
\hline 6. & $\begin{array}{l}\text { Mengaitkan materi matematika dengan masalah dalam } \\
\text { kethidupan setari-hari }\end{array}$ & 57,01 & Cukup \\
\hline 7. & $\begin{array}{l}\text { Siswa merasa senang dengan materi-materi matematika } \\
\text { yang baru }\end{array}$ & 71,37 & Tinggi \\
\hline 8. & Siswa merasa senang mengerjakan soal matematika & 60,01 & Tinggi \\
\hline 9. & $\begin{array}{l}\text { Siswa merasa gigih untuk menemukan jawahan atas } \\
\text { pernuasalahan malematika }\end{array}$ & 65,11 & Tinggi \\
\hline 10. & $\begin{array}{l}\text { Siswa menyediakan waktu khusus untuk belajar } \\
\text { matematka di luar sckolah }\end{array}$ & 67,78 & Tinggi \\
\hline 11. & $\begin{array}{l}\text { Senang memperhatikan dan mengerjakan soal-soal } \\
\text { latihan matematika }\end{array}$ & 63,97 & Tinggi \\
\hline 12. & Selalu berpartisipasi dalam seliap proses pembelajaran & 59,43 & Cukup \\
\hline $\begin{array}{l}13 . \\
14 .\end{array}$ & $\begin{array}{l}\text { Akrif ketika helajar berkelompok maupun indivitu } \\
\text { Mencari materi/solusi atas permasalahan }\end{array}$ & $\begin{array}{l}74,18 \\
64,09\end{array}$ & $\begin{array}{l}\text { Tinggi } \\
\text { Tinggi }\end{array}$ \\
\hline 15. & $\begin{array}{l}\text { Berusaha meayelesuikan permasalahan dengan } \\
\text { menggunakan cara sendiri }\end{array}$ & 68,21 & Tinggi \\
\hline 10. & Menemukan metodc lain yang Icbih mudah digunakan & 47,14 & Cukup \\
\hline
\end{tabular}

Angket tersebut disusun ke dalam 25 item pertanyaan yang menerangkan tingkat rasa percaya diri siswa. Sebelum dianalisis, data tersebut diubah dari data ordinal menjadi interval dengan menggunakan Method Successive Interval. setelah data tersebut diubah maka didapat untuk skor maksimal 4,85 dan skor minimal adalah 1,00. Dari hasil penyebaran angket tersebut, dengan menggunakan program SPSS 17,0 diperoleh data deskripsi statistik yang disajikan dalam tabel 3

Descriptive Statisties

\begin{tabular}{|l|r|r|r|r|r|r|}
\hline & N & Mirimum & Maximum & Meim & Shi. Deviafion & Vuriante \\
\hline $\begin{array}{l}\text { Kasa Percaya Diri } \\
\text { Siswa } \\
\text { Valid N (listwise) }\end{array}$ & 89 & 49 & 86 & 66.43 & 7.559 & 57.133 \\
\hline
\end{tabular}

Berdasarkan hasil perhitungan dengan menggunakan program SPSS.17.0, diperoleh output analisis statistik. Hasil tersebut menunjukkan bahwa siswa skor minimal yang diperoleh siswa terkait rasa percaya diri siswa adalah 49 dan dikategorikan memiliki rasa percaya siswa yang cukup, sedangkan skor maksimal yang diperoleh siswa adalah 86 dengan kategori sangat tinggi. Skor rata-rata (mean) rasa percaya diri siswa diperoleh 66,43, maka dapat dikategorikan bahwa rasa percaya diri siswa kelas VII MTs
Negeri I Cirebon tergolong tinggi. Adapun standar deviasi yang diperoleh melalui skala pengukuran rasa percaya diri siswa adalah 7.559 dan nilai variannya sebesar 57.133. Hal ini menunjukkan bahwa data tersebut bervariasi.

Perbandingan besaran tingkat rasa percaya diri siswa untuk setiap indikatornya, dapat diketahui pada dara rekapitulasi hasil rasa percaya diri siswa. Berikut ini adalah data rekapitulasi hasil rasa percaya diri yang disajikan pada tabel 4 dibawah ini. 


\begin{tabular}{|c|c|c|c|}
\hline \multicolumn{4}{|c|}{ Rekapitulasi Rasa Percaya Diri Siswa } \\
\hline No & Indikator & Interpretasi & Ket \\
\hline 1. & Yakin terhadap kemampuan belajar matematika & $68,00^{\mathrm{n}} \%$ & Tinggi \\
\hline 2. & Rasa ingin mencoba mencerjakan soal-scal matematika & $66,05 \%$ & Tinggi \\
\hline 3. & Rasa tertarik pada pelajaran matematika & $69,85 \%$ & Tinggi \\
\hline 4. & Rasa tcrtantang untuk menyclesaikan soal-soal matcmatika & $65,35 \%$. & linggi \\
\hline 5. & lessa bangga atas prestasi belajar matematika & $53,42 \%$ & Cukup \\
\hline 6. & Adanya kemampuan siswa dalam mempelajari matematika & $77,15 \%$ & linggi \\
\hline 7. & Domngan untuk menjadi lehih haik & $78,07 \%$ & Tinggi \\
\hline 8. & Kegigihan dalam memperjuangkan sasaran & $77.53 \%$ & Tinggi \\
\hline 9. & $\begin{array}{l}\text { Siswa tidak mudah menyerah ketika mendapatkan } \\
\text { persoclan yang sulit }\end{array}$ & $70.60 \%$ & Tinggi \\
\hline 10. & Yakin ates pendapat/ide/gagasan diri sendiri & $61,02 \%$ & Tinggi \\
\hline 11. & Mampu menycsuaikan diri & $02,93 \%$ & Tinggi \\
\hline 12. & Bersikap tenang & $65,17 \%$ & Tinggi \\
\hline
\end{tabular}

Dari data tersebut diperoleh rata-rata tingkat rasa percaya diri siswa kelas VII MTs Negeri I Cirebon sebesar 66,43 dengan kriteria yang tinggi. Besarnya tingkat rasa percaya diri siswa dipengaruhi oleh beberapa faktor, antara lain keyakinan terhadap kemampuan belajar matematika, minat belajar matematika, antusias pada pelajaran matematika, motivasi dalam belajar matematika tidak mudah menyerah. Tidak takut salah dan konsep diri yang baik. Faktor tersebut memberikan kontribusi yang cukup besar dalam mempengaruhi tingkat rata rata rasa percaya diri siswa.

Sedangkan hasil perhitungan untuk data hasil belajar siswa dapat dilihat dari tabel berikut.

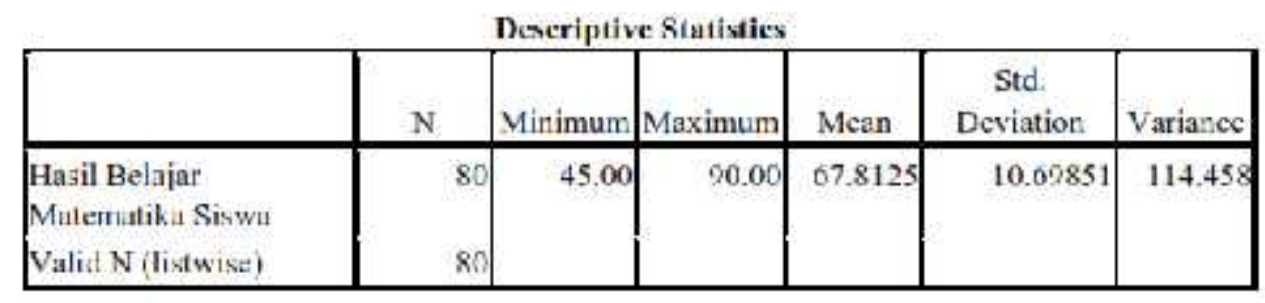

Berdasarkan data diatas, didapatkan nilai rata-rata (mean) hasil belajar matematika siswa kelas VII di MTs Negeri I Cirebon yaitu sebesar 67.8125. adapun skor minimal yang diperoleh siswa dari hasil belajar matematika siswa sebesar 45.00. sedangkan untuk skor maksimal yang didapat 90.00.dengan nilai standar deviasi
10.69851 dan nilai variansnya didapat 114,458 . Hal ini menunjukkan bahwa data tersebut bervariasi.

Perbandingan perindikatornya mengenai hasil belajar matematika yang telah dicapai oleh siswa kelas VII MTs Negeri I Cirebon dapat dilihat pada tabel 5 sebagai berikut: 
Rekapitulasi Hasil Belajar

\begin{tabular}{|c|c|c|c|}
\hline No & Indlkator & Interpretasl & Ket \\
\hline 1 & $\begin{array}{l}\text { Menyatakan thasalah sehari-hari dalam beniuk } \\
\text { himpunan dan mendata anggotarya }\end{array}$ & 87,50 & $\begin{array}{l}\text { Sangal } \\
\text { Baik }\end{array}$ \\
\hline 2 & $\begin{array}{l}\text { Menyebutkan anggota dan bukan anggota suatu } \\
\text { himpunan }\end{array}$ & 57,50 & Cukup \\
\hline 3 & Menyatakan notasi himpunan & 68,75 & Cukшn \\
\hline$\overline{4}$ & Menielaskan himpunan kosong dan notnsiny. & 88.75 & $\begin{array}{c}\text { Sangat } \\
\text { Baik }\end{array}$ \\
\hline 5 & $\begin{array}{l}\text { Menentukan himpunan hrgian dari suatu } \\
\text { himpunan }\end{array}$ & 31,25 & $\begin{array}{l}\text { Sangit } \\
\text { Kurang }\end{array}$ \\
\hline 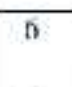 & $\begin{array}{l}\text { Menentuknn hanyak himpunan hagian suatu } \\
\text { himpunau }\end{array}$ & 25 & $\begin{array}{l}\text { Sangnt } \\
\text { Kurang }\end{array}$ \\
\hline 7 & $\begin{array}{l}\text { Meniclaskan peogertian himpunan semesta, } \\
\text { serta dapal menyebulkan anggotanyd }\end{array}$ & 87,5 & $\begin{array}{l}\text { Sangat } \\
\text { Baik }\end{array}$ \\
\hline 8 & $\begin{array}{l}\text { Menjelaskan pengertian irisan gabungan dan } \\
\text { selisih dari dun himpunnn }\end{array}$ & 50 & Cukup \\
\hline 9 & $\begin{array}{l}\text { Menentukan irisan, gabungan dan selisih vua } \\
\text { himpunan }\end{array}$ & 69,94 & Cukup \\
\hline 10 & $\begin{array}{l}\text { Menjelaskan pengerian komplemen dar suntu } \\
\text { himpunan }\end{array}$ & 75 & Baik \\
\hline 11 & Menentukan komplettien dari suatu himpunan & 73,75 & Baik \\
\hline 12 & $\begin{array}{l}\text { Menyajikan gabungan atau irisan dua } \\
\text { himpunan dengan diagran venn }\end{array}$ & 76,25 & Baik \\
\hline 13 & $\begin{array}{l}\text { Menyajikan selisih suafu himpunan dari } \\
\text { himpunan lainnya dengan diagran venn }\end{array}$ & 82.5 & Baik \\
\hline 14 & Menyajikan komplemen suatu himpunan & 70,25 & Baik \\
\hline 15 & $\begin{array}{l}\text { Menyelesaikan masalah dengan menggunakan } \\
\text { diagram venn dan knnsep himpunan }\end{array}$ & 82.5 & Baik \\
\hline
\end{tabular}

Data di atas menunjukkan bahwa dalam menyatakan masalah sehari-hari dalam bentuk himpunan dan mendata anggotanya dan menjelaskan himpunan kosong dan notasinya serta menjelaskan pengertian himpunan semesta, serta dapat menyebutkan anggotanya dinilai sangat baik. Indikator tersebut menunjukkan bahwa siswa kelas VII MTs Negeri I Cirebon lebih mudah dalam menghafal pengertian dari himpunan serta mendata anggotanya, menghafal pengertian himpunan serta mendata anggotanya dan menghafal pengertian himpunan semesta dan anggotanya. Namun pada indikator lainnya dinyatakan baik dan cukup. Hanya saja pada indikator menentukan himpunan bagian pada suatu himpunan dinyatakan kurang.

Uji kelinieran regresi dilakukan dengan tujuan untuk mengetahui ada tidaknya hubungan yang dimiliki oleh dua variabel secara signifikan. Adapun hasil yang diperoleh dari uji kelinieran regresi yang dilakukan dengan menggunakan program SPSS.17.0 dapat dilihat pada tabel 6 sebagai berikut :

IIasil Uji Kelinieran Regresi ANOVA Tahic

\begin{tabular}{|c|c|c|c|c|c|c|c|}
\hline & & & Sum of Squares & $\mathrm{df}$ & $\begin{array}{l}\text { Mean } \\
\text { Square }\end{array}$ & $\mathrm{F}$ & Sig. \\
\hline \multirow{5}{*}{$\begin{array}{l}\text { Rasa Pcreay } \\
\text { Dir Siswa } \\
\text { Keinginmahi } \\
\text { n. Siswa }\end{array}$} & Between & (Combined) & 3934.974 & 41 & 95.975 & 6.080 & 327 \\
\hline & Gimups & Timearily & 1.483 .543 & 1 & 1483.543 & 103,348 & .005 \\
\hline & & $\begin{array}{l}\text { Deviation from } \\
\text { Lincarity }\end{array}$ & 2451.431 & 40 & 01.285 & 4.209 & .194 \\
\hline & \multicolumn{2}{|c|}{ Within Groups } & 545.481 & 38 & $14.35=$ & & \\
\hline & \multicolumn{2}{|l|}{ Total } & 4480.455 & 70 & & & \\
\hline
\end{tabular}

Dari hasil di atas diperoleh signifikansi dari Linearity sebesar $0,005<0,05$. Maka dapat 
dinyatakan bahwa keingintahuan siswa berpengaruh terhadap rasa percaya diri siswa.

Uji otokorelasi dilakukan untuk mengetahui tidak adanya masalah otokorelasi, dengan demikian hasil penelitian tersebut dapat dijadikan sebagai syarat untuk melakukan analsis regresi ganda. Untuk menghitung uji otokorelasi tersebut menggunakan formula DurbinWatson pada program SPSS.17.0. Adapun hasiln uji otokorelasi dapat dilihat pada tabel 7 sebagai berikut.

\section{Hasil Uji Otokorelasi}

Model Summary ${ }^{\mathrm{B}}$

\begin{tabular}{|l|c|r|r|r|r|}
\hline Model & R & R Square & $\begin{array}{c}\text { Adjusted R } \\
\text { Square }\end{array}$ & $\begin{array}{c}\text { Std. Error of } \\
\text { the Estimate }\end{array}$ & $\begin{array}{c}\text { Durbin- } \\
\text { Watson }\end{array}$ \\
\hline 1 & $.210^{9}$ & .044 & .219 & 10.594 & 1.690 \\
\hline
\end{tabular}

a. Predictors: (Constant), Rasa Percaya Diri Siswa, Keingintahuan Siswa

b. Dependent Variable: Hasil Belajar Matematika

Berdasarkan hasil tabel di atas, nilai-nilai Durbin-Watson adalah 1,690. Sementara nilai Durbin-Watson untuk $n=80$ adalah $\mathrm{dL}=1,585$ dan $\mathrm{dU}=1,688$. Nilai DurbinWatson hitung $(\mathrm{d}=1,690)$ yang didapat dinyatakan lebih besar dari pada batas atas nilai Durbin-Watson tabel $(\mathrm{dU}=$ 1,688) dan lebih kecil daripada $(4-1,688=$
2,312), maka H0 ditolak yang artinya tidak terdapat masalah otokorelasi.

Uji spearman's rho pada penelitian ini dilakukan dengan menggunakan program SPSS 17.0. adapun hasil uji korelasi spearman's rho disajikan pada tabel 9 sebagai berikut:

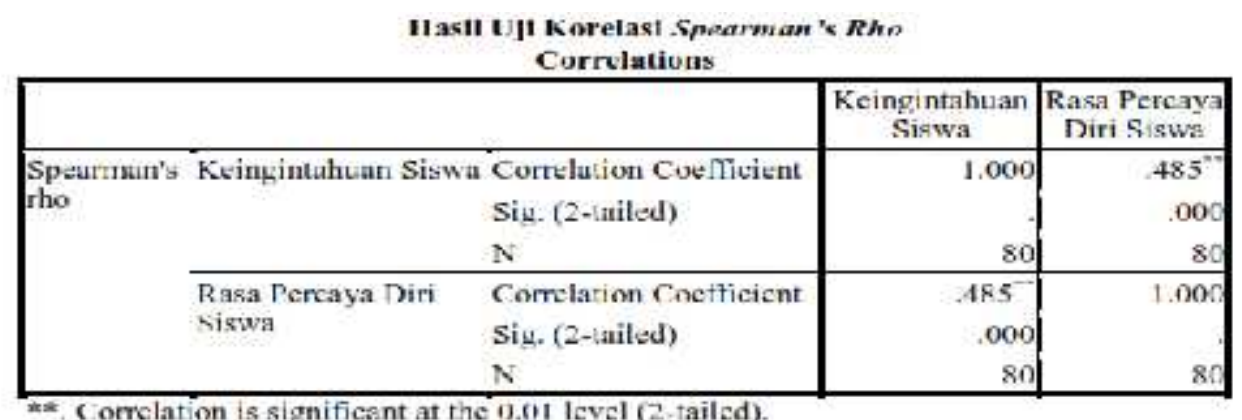

Berdasarkan hasil tersebut diperoleh nilai korelasi dari keingintahuan terhadap rasa percaya diri siswa sebesar 0,485 , hal ini tergolong cukup. Adapun nilai signifikansi dari korelasi tersebut diperoleh nilai sebesar

$0,000<0,05$. Artinta, dapat dinyatakan bahwa terdapat pengaruh antara keingintahuan dan rasa percaya diri siswa. Hasil pengujian secara parsial dapat dilihat pada tabel berikut:

Coefficients ${ }^{2}$

\begin{tabular}{|c|c|c|c|c|c|c|c|}
\hline \multirow[b]{2}{*}{ Model } & \multicolumn{2}{|c|}{$\begin{array}{l}\text { Unstandardized } \\
\text { Coellicients }\end{array}$} & \multirow{2}{*}{\begin{tabular}{c|}
$\begin{array}{c}\text { Standardized } \\
\text { Coclficients }\end{array}$ \\
Beta
\end{tabular}} & \multirow[b]{2}{*}{$t$} & \multirow[b]{2}{*}{ Sig. } & \multicolumn{2}{|c|}{$\begin{array}{l}\text { Collinearity } \\
\text { Statistics }\end{array}$} \\
\hline & B & $\begin{array}{c}\text { Std } \\
\text { Lirror } \\
\end{array}$ & & & & \begin{tabular}{|c|} 
Tolemnc \\
$\mathrm{c}$
\end{tabular} & VIF \\
\hline 1 (Constant) & 83,800 & 10.065 & & 7.804 & .127 & & \\
\hline $\begin{array}{l}\text { Keingintahu } \\
\text { an Siswa }\end{array}$ & .128 & .137 & .128 & .937 & .009 & .669 & 1.495 \\
\hline $\begin{array}{l}\text { Rasa } \\
\text { Perceaya Diri } \\
\text { Siswa }\end{array}$ & 364 & .194 & 256 & 1.879 & .000 & .609 & 1.495 \\
\hline
\end{tabular}

a. Dependent Varable: Hosil Relajar Mutemarika 
Berdasarkan hasil tabel di atas, signifikansi untuk variabel keingintahuan siswa adalah $0,009<0,05$ dan signifikansi untuk variabel rasa percaya diri siswa adalah $0,000<0,05$. Artinya, dapat dikatakan bahwa keingintahuan siswa dan rasa percaya diri siswa mempunyai pengaruh terhadap hasil belajar. Besarnya pengaruh langsung variabel keingintahuan siswa dan variable rasa percaya diri siswa terhadap variabel hasil belajar ditunjukkan oleh Standardized Coefficients Beta yaitu sebesar 0, 128 dan 0,256 , dandiperoleh nilai koefisien arah a1 sebesar 0,128 dan a2 sebesar 0,364. Konstanta (a) sebesar 83,866 sehingga persamaan regresinya adalah sebagai berikut: $\mathrm{Y}=\mathrm{a} 0+\mathrm{a} 1 \mathrm{X} 1+\mathrm{a} 2 \mathrm{X} 2=83.866+$ $0,128 \mathrm{X} 1+0,364 \mathrm{X} 2+0,128$ keingintahuan siswa $+0,364$ rasa percaya diri siswa.

\section{PEMBAHASAN}

Harlen (Darmodjo dan Kaligis, 1991: 8) menjelaskan bahwa curiosity sebagai bagian dari sikap ilmiah adalah suatu sikap yang selalu ingin mendapatkan jawaban yang benar dari obyek yang diamati. Seseorang akan termotivasi untuk belajar karena adanya rasa ingin tahu yang timbul dari perasaan penasaran. Ketika proses membaca telah dapat memuaskan naluri curiosity maka yang terjadi adalah rasa senang, dan ada keinginan kuat untuk mengulanginya lagi, sehingga mulailah terbentuknya minat (Utami, 2006). Adapun berdasarkan hasil penelitian yang dilakukan di MTs Negeri I Cirebon menerangkan bahwa tingkat rata-rata keingintahuan siswa kelas VII di MTs Negeri I Cirebon tergolong tinggi yaitu berada pada angka 63,34. Kondisi tersebut dipengaruhi oleh intensitas siswa dalam menanyakan gagasan sendiri atau orang lain, respon positif siswa dalam pembelajaran, siswa merasa senang dengan materi-materi matematika yang baru, Siswa merasa senang mengerjakan soal matematika, Siswa merasa gigih untuk menemukan jawaban atas permasalahan matematika, Siswa menyediakan waktu kh usus untuk belajar matematika di luar sekolah, senang memperhatikan dan mengerjakan soalsoal

latihan matematika, aktif ketika belajar berkelompok maupun individu, mencari materi/solusi atas permasalahan, dan berusaha menyelesaikan permasalahan dengan menggunakan cara sendiri. Adapun indikator lain seperti berinisiatif menambah wawasan berkontribusi dalam diskusi, siswa menjadi pengamat yang baik, mengaitkan materi matematika dengan masalah dalam kehidupan sehari-hari, selalu berpartisipasi dalam setiap proses pembelajaran, menemukan metode lain yang lebih mudah digunakan juga turut mendukung tingkat keingintahuan siswa, hanya saja indikator-indikator tersebut kurang memberikan nilai yang signifikan. Hal tersebut dikarenakan siswa-siswi di MTs Negeri I Cirebon telah terbiasa dengan metode ceramah jadi siswa kurang memberikan kontribusi saat berdiskusi dan tidak banyak berpartisipasi saat proses pembelajaran, juga siswa-siswa MTs Negeri I cirebon tidak terlalu memperhatikan lingkungan sekitar yang berhubungandengan pelajaran matematika. Jadi, siswa tersebut belum mengaitkan materi matematika dalam kehidupan seharihari. Siswa-siswi MTs Negeri I Cirebon juga terbiasa menggunakan metode yang diajarkan oleh guru karena khawatir jika menggunakan metode lain akan disalahkan. Sementara itu, percaya diri merupakan keyakinan dalam diri seseorang untuk dapat menangani segala sesuatu yang ada dihadapannya dengan tenang. Percaya diri merupakan keyakinan yang kuat dalam diri yang berupa perasaan dan anggapan bahwa dirinya dalam keadaan baik sehingga memungkinkan individu tampil dan berperilaku dengan penuh keyakinan (Hambly, 1995:3).

Berdasarkan hasil penelitian yang dilakukan di MTs Negeri I Cirebon menerangkan bahwa tingkat rata-rata rasa percaya diri siswa kelas VII di MTs Negeri I Cirebon dinyatakan tinggi dengan skor rata-rata 66,43. Rasa percaya diri siswa 
tersebut lebih banyak dipengaruhi oleh indikator keyakinan terhadap kemampuan belajar matematika yang dimiliki siswa, rasa ingin mencoba mengerjakan soal-soal matematika, rasa tertarik pada pelajaran matematika, rasa tertantang untuk menyelesaikan soal-soal matematika, adanya kemampuan siswa dalam mempelajari matematika, dorongan untuk menjadi lebih baik, kegigihan dalam memperjuangkan sasaran, siswa tidak mudah menyerah ketika mendapatkan persoalan yang sulit, yakin atas pendapat/ide/gagasan diri sendiri, bersikap tenang, mampu menyesuaikan diri. Adapun indikator perasaan bangga atas prestasi yang diraihnya hanya memberikan pengaruh yang tidak cukup besar, dikarenakan siswa-siswi kelas VII di MTs Negeri I Cirebon telah ditanamkan dalam dirinya untuk tetap rendah hati dan tidak sombong. Sehingga siswa tidak cepat merasa puas atas prestasi yang dircapai. Dengan begitu, siswa akan terus berusaha dan belajar untuk menggapai apa yang diinginkan.

Hasil belajar matematika siswa sangat dipengaruhi oleh beberapa faktor. menurut Suryabrata (1987: 233), faktor yang mempengaruhi prestasi belajar dapat berupa : (1) faktor belajar yang berasal dari luar diri si pelajar yaitu lingkungan (lingkungan alami dan lingkungan sosial), instrumental (kurikulum, program, sarana dan guru), (2) faktor yang berasal dari dalam diri si pelajar faktor fisiologis (kondisi fisik secara umum, kondisi panca indera danfaktor psikologis (minat, kecerdasan, bakat, motivasi dan kemampuan kognitif). Prestasi belajar adalah hasil yang telah dicapai (dan yang telah dilakukan, dikerjakan). Hasl penelitian yang telah dilakukan di MTS Negeri I Cirebon menunjukkan bahwa ratarata hasil belajar matematika yang diperoleh siswa kelas VII tergolong cukup, yaitu dengan nilai rata-rata sebesar 67,81. Berdasarkan nilai yang telah diperoleh siswa peneliti menyatakan bahwa tingkat kemampuan siswa dalam memahami materi matematika sangat bergantung pada kemampuan dasar yang dimilikinya. Hal ini dilihat dari besarnya persentase yang telah dianggap tuntas untuk setiap indikator menunjukkan angka yang sangat linier, artinya apabila indikator awal sudah dianggap tuntas maka siswa akan lebih mudah untuk memahami materi pada indikator selanjutnya, dan sebaliknya apabila indikator awalbelum dikuasai oleh siswa maka siswa akan lebih sulit dalam memahami indikator berikutnya.

Tingkat rata-rata keingintahuan siswa dan rasa percaya diri siswa dengan masingmasing interpretasi sebesar 63,34 dan 66,43 . Apabila dihubungkan dengan hasil belajar matematika siswa yang nilai rataratanya sebesar 67,81 dengan kategori cukup, terdapat hubungan yang linier. Hasil perhitungan Uji Statistik yang dilakukan dengan menggunakan program SPSS.17.0 diperoleh nilai signifikan sebesar 0,009 untuk keingintahuan siswa dan 0,000 untuk variabel rasa percaya diri siswa, yang artinya hal tersebut menunjukkan adanya hubungan yang linier. Hasil uji analisis diketahui bahwa pengaruh yang diberikan oleh keingintahuan dan rasa percaya diri siswa masing-masing sebesar 0,128 dan 0,364 , yang artinya rasa percaya diri siswa lebih banyak memberikan pengaruh terhadap hasil belajar matematika.

Berdasarkan hasil koefisien regresi dapat diketahui bahwa terdapat pengaruh keingintahuan dan rasa percaya diri siswa secara bersama-sama terhadap hasil belajar matematka. Pengaruh yang diberikan adalah sebesar 4,79\%. Adapun besar pengaruh sisanya yaitu dipengaruhi oleh faktor-faktor lain. Faktor-faktor lain menurut Djamarah (2008 : 176) yang turut mempengaruhi hasil belajar siswa antara lain seperti faktor lingkungan (alam, sosial budaya), faktor instrumental (kurikulum, program, sarana dan fasilitas), faktor fisiologis dan faktor psikologis (bakat). Dengan demikian hasil penelitian ini dapat disimpulkan bahwa terdapat pengaruh antara keingintahuan dan rasa percaya diri 
siswa terhadap hasil belajar matematika siswa kelas VII MTs Negeri I Cirebon.

\section{KESIMPULAN DAN SARAN}

1. Besarnya keingintahuan siswa kelas VII MTs Negeri I Cirebon tergolong tinggi, yaitu berada pada angka 63,34. Seangkan besarnya rasa percaya diri siswa kelas VII MTs Negeri I Cirebon dapat dinyatakan tinggi, dengan nilai interpretasi sebesar 66,43.

2. Terdapat pengaruh yang signifikan antara keingintahuan siswa dengan hasil belajar matematika siswa kelas VII MTs Negeri I Cirebon. Hasil analisis diperoleh nilai signifikansi sebesar $0,009<0,05$. Adapun besarnya pengaruh langsung yang diberikan keingintahuan terhadap hasil belajar matematika ditunjukkan oleh Standardized Coefficients Beta sebesar 0,128.

3. Terdapat pengaruh yang signifikan antara rasa percaya diri siswa dengan hasil belajar matematika siswa kelas VII di MTs Negeri I Cirebon. Hasil analisis menunjukkan nilai signifikasi kesiapan belajar sebesar $0,000<$ 0,05 . Adapun besarnya pengaruh langsung yang diberikan kesiapan belajar matematika terhadap hasil belajar matematika ditunjukkan oleh Standardized Coefficients Beta sebesar 0,256. Artinya faktor rasa percaya diri siswa lebih besar mempengaruhi hasil belajar matematika siswa dibandingkan dengan faktor keingintahuan siswa.

4. Hasil analisis koefisien regresi menunjukkan bahwa terdapat pengaruh antara keingintahuan dan rasa percaya diri siswa terhadap hasil belajar matematika siswa kelas VII MTs Negeri 1 Cirebon. Hasil analisis dari uji hipotesis yang diajukan menunjukkan bahwa nilai statistik $\mathrm{F}$ yang diperoleh adalah 11,782 dengan nilai signifikan (prob F statistik $=0,000)<0,05$. Sementara itu besarnya variabilitas hasil belajar matematika yang dipengaruhi oleh keingintahuan dan rasa percaya diri siswa sebesar 4,79\%. Hal ini berarti bahwa hasil belajar matematika siswa kelas VII MTs Negeri I Cirebon sebesar 4,79 $\%$ dipengaruhi oleh keingintahuan dan rasa percaya diri siswa, sedangkan sisanya sebesar $95,21 \%$ dipengaruhi oleh faktor lain.

Saran

1. Kepada para siswa hendaknya dapat mengembangkan rasa ingin tahu yang sebenarnya secara alami sudah tumbuh dalam dirinya semenjak usia dini. Rasa ingin tahu akan mendorong diri siswa untuk belajar.

2. Kepada para guru khususnya guru bidang studi matematika, diharapkan selama proses pembelajaran dapat membangkitkan rasa ingin tahu, terutama dalam meningkatkan motivasi belajar dan membuat siswa senang setelah mengikuti proses pembelajaran matamatika, dengan berbagai model dan gaya pembelajaran yang mampu menarik perhatian siswa

\section{DAFTAR PUSTAKA}

Abdullah, Aly. 2011. Ilmu Alamiah Dasar. Jakarta: PT Bumi Aksara.

Arikunto, Suharsimi. 2002. Prosedur

Penelitian Suatu Pendekatan

Praktek. Jakarta: Rineka Bandung:

Alfabeta Cipta.

Darsono, dkk. 2000. Belajar dan

Pembelajaran. Semarang: IKIP

Semarang Press

Dengan Memperhatikan Keingintahuan

Siswa Pada Materi Kelarutan Dan Hasil Kali

Dimyati, dkk. 1994. Belajar dan

Pembelajaran. Jakarta : Proyek

Pembinaan dan Peningkatan Mutu 
Kependidikan, Dirjen Dikti Depdikbud.

Djamarah, Syaiful Bahri. 2002. Rahasia

Sukses Belajar. Jakarta: Rineka

Cipta.

Hakim, Thursan. 2002. Mengatasi Rasa

Tidak Percaya Diri. Jakarta: Puspa Swara.

Hudzaifah. 2013. Pembelajaran Fungsi

Komposisi dan Fungsi Invers

Melalui Pendekatan

Ilawati, Emi, dkk. 2015. Studi Komparasi

Penggunaan Metode Tai Dan

Problem Solving Islam Indonesia.

Yogyakarta: UIN

Kelarutan Siswa Kelas Xi Sma Negeri 1

Surakarta Tahun Pelajaran

2014/2015. Jurnal

Mahasiswa Jurusan Psikologi Fakultas

Psikologi Dan Ilmu Sosial Budaya

Universitas

Maskoeri Jasin (2002). Ilmu Alamiah

Dasar. Jakarta: PT Raja Grafindo

Persada.Matematika Realistik

untuk Meningkatkan Hasil Belajar

Siswa SMA. Malang: UNM

Muhidin, Sambas Ali dan Maman

Abdurrahman. 2007. Analisis

Korelasi Regresi dan Jalur dalam

Penelitian: Dilengkapi Aplikasi

Program SPSS. Bandung: CV

Pustaka Setia

Patta Bundu. (2006). Penilaian

Keterampilan Proses dan Sikap
Ilmiah dalam Pembelajaran Sains

SD. Jakarta: Depdikbud.

Pendidikan Kimia. Vol. 4 No. 3. Surakarta: FKIP UNS.

Pudjijugyanti, Clara R. 1988. Konsep Diri dalam Pendidikan. Jakarta: Arcan.

Purwanto, Ngalim. 1998. Psikologi Pendidikan. Bandung: PT. Remaja Rosdakarya

Riduwan. 2006. Belajar Mudah Penelitian untuk Guru-Karyawana dan Peneliti Pemula.

Riduwan. 2008. Dasar-Dasar Statistik. Bandung: Alfabeta.

Sudjana, N. 2005. Dasar-dasar Proses Belajar Mengajar. Bandung: Sinar Baru Algesindo

Sudjana. 2005. Metoda Statistika. Bandung : PT. Tarsito

Sugiyono. 2013. Metode Penelitian Kuantitatif, Kualitatif, dan $R \& D$. Bandung: Alfabeta.

Sulistyaningsih, Dwi dan Joko Iswahyudi. 2012. Meningkatkan Hasil Belajar Matematika Siswa Melalui Metode Pembelajaran Jigsaw Berbantuan Cd Pembelajaran Ma Teri Ekponen Kelas X. Jurnal Seminar Hasil-hasil Pendidikan. Semarang.: Unimus.

Utami, Ratna Dewi Galuh, dkk. 2006. Hubungan Curiosity Dengan Minat Membaca Pada

Willis, Ratna. 2002. Teori-teori Belajar. Bandung : PT. Gelora Aksara 